\title{
Carbon balance of UK peatlands: current state of knowledge and future research challenges
}

\author{
M. F. Billett ${ }^{1, *}$, D. J. Charman ${ }^{2}$, J. M. Clark $^{3,8}$, C. D. Evans ${ }^{4}$, M. G. Evans ${ }^{5}$, N. J. Ostle ${ }^{6}$, \\ F. Worrall ${ }^{7}$, A. Burden ${ }^{4}$, K. J. Dinsmore ${ }^{1}$, T. Jones ${ }^{4}$, N. P. McNamara ${ }^{6}$, L. Parry ${ }^{2}$, \\ J. G. Rowson ${ }^{7}$, R. Rose $^{6}$ \\ ${ }^{1}$ Centre for Ecology \& Hydrology, Bush Estate, Penicuik, Midlothian EH26 0QB, UK \\ ${ }^{2}$ School of Geography, University of Exeter, Exeter EX4 4QJ, UK \\ ${ }^{3}$ Wolfson Carbon Capture Laboratory, School of Biological Sciences, Bangor University, Deiniol Road, Bangor, \\ Gwynedd LL57 2UW, UK \\ ${ }^{5}$ Department of Geography, School of Environment \& Development, University of Manchester, Oxford Road, \\ Manchester M13 9PL, UK \\ ${ }^{6}$ Centre for Ecology \& Hydrology, Library Avenue, Bailrigg, Lancaster LA1 4AP, UK \\ ${ }^{7}$ Department of Earth Sciences, Science Laboratories, South Road, Durham DH1 3LE, UK

\begin{abstract}
${ }^{8}$ Present address: Walker Institute for Climate Systems Research and Soils Research Centre, Department of Geography and Environmental Science, School of Human and Environmental Sciences, University of Reading, Whiteknights, PO Box 233, Reading RG6 6DW, UK
\end{abstract}

\begin{abstract}
The retention of peatland carbon (C) and the ability to continue to draw down and store $\mathrm{C}$ from the atmosphere is not only important for the UK terrestrial carbon inventory, but also for a range of ecosystem services, the landscape value and the ecology and hydrology of $\sim 15 \%$ of the land area of the UK. Here we review the current state of knowledge on the C balance of UK peatlands using several studies which highlight not only the importance of making good flux measurements, but also the spatial and temporal variability of different flux terms that characterise a landscape affected by a range of natural and anthropogenic processes and threats. Our data emphasise the importance of measuring (or accurately estimating) all components of the peatland $\mathrm{C}$ budget. We highlight the role of the aquatic pathway and suggest that fluxes are higher than previously thought. We also compare the contemporary $\mathrm{C}$ balance of several UK peatlands with historical rates of $\mathrm{C}$ accumulation measured using peat cores, thus providing a long-term context for present-day measurements and their natural year-on-year variability. Contemporary measurements from 2 sites suggest that current accumulation rates $\left(-56\right.$ to $\left.-72 \mathrm{~g} \mathrm{C} \mathrm{m}^{-2} \mathrm{yr}^{-1}\right)$ are at the lower end of those seen over the last $150 \mathrm{yr}$ in peat cores $\left(-35\right.$ to $\left.-209 \mathrm{~g} \mathrm{C} \mathrm{m}^{-2} \mathrm{yr}^{-1}\right)$. Finally, we highlight significant current gaps in knowledge and identify where levels of uncertainty are high, as well as emphasise the research challenges that need to be addressed if we are to improve the measurement and prediction of change in the peatland $\mathrm{C}$ balance over future decades.
\end{abstract}

KEY WORDS: Carbon $\cdot$ Peatland $\cdot$ Peat $\cdot$ DOC $\cdot$ Flux $\cdot$ Aquatic

Resale or republication not permitted without written consent of the publisher

\section{INTRODUCTION}

Peatlands cover $\sim 15 \%$ of the land area of the UK and, while estimates of carbon stored in peatland have varied in the past (Milne \& Brown 1997, Bradley et al. 2005), the best current value is $2302 \mathrm{Mt} \mathrm{C}$ (R. Milne pers. comm.). This is based on the estimate for Scotland from Chapman et al. (2009) combined with data from Bradley et al. (2005) and Smith et al. (2007), with the addition of pro rata estimates for England and Northern Ireland, as peat stocks below $1 \mathrm{~m}$ are not well characterised (Table 1).

Although UK peatlands form a relatively small part of the peatlands of the northern boreal and temperate regions, they are of national and international importance for a number of reasons. Many of them are bio- 
Table 1. UK peatland area and carbon storage based on information from a number of sources

\begin{tabular}{|c|c|c|c|c|}
\hline \multirow{2}{*}{ Country } & \multirow[b]{2}{*}{$\begin{array}{l}\text { Area } \\
\left(\mathrm{km}^{2}\right)\end{array}$} & \multicolumn{2}{|c|}{ Soil depth } & \multirow[b]{2}{*}{$\begin{array}{c}\text { Total } \\
\text { (Mt C) }\end{array}$} \\
\hline & & $\begin{array}{c}0-100 \mathrm{~cm} \\
(\mathrm{Mt} \mathrm{C})\end{array}$ & $\begin{array}{c}>100 \mathrm{~cm} \\
(\mathrm{Mt} \mathrm{C})\end{array}$ & \\
\hline Scotland & 17789 & $1104^{\mathrm{a}}$ & $516^{\mathrm{a}}$ & 1620 \\
\hline England & 4246 & $296^{b}$ & $123^{\mathrm{d}}$ & 419 \\
\hline Wales & 732 & $67^{\mathrm{b}}$ & $52^{\mathrm{c}}$ & 119 \\
\hline Northern Ireland & 1873 & $90^{\mathrm{b}}$ & $54^{\mathrm{d}}$ & 144 \\
\hline UK & 24640 & 1557 & 745 & 2302 \\
\hline
\end{tabular}

sphere or nature reserves, they are archives of change and provide significant water resources to large and often densely populated parts of the country. They comprise a significant proportion of the total UK soil carbon (C) pool, with the most extensive areas of peat development in the cooler, wetter (mainly upland) areas of the UK. The long-term viability of peatlands is based upon their ability to continue to draw down and store more $\mathrm{C}$ from the atmosphere than they lose via a number of different export pathways. Whilst researchers now recognise the range of flux pathways (inputs and outputs) and the various forms of $\mathrm{C}$ involved (gases, solutes and particulates), there is a continuous need to improve measurement and scaling techniques and reduce levels of uncertainty in the overall C balance.

Carbon accumulation in UK peatlands started at the end of the last ice age and over the last 8000 to $10000 \mathrm{yr}$ rates has fluctuated due to changes in external factors such as temperature and precipitation (Charman 2002). The current consensus is that Gorham's (1991) value of $-23 \mathrm{~g} \mathrm{C} \mathrm{m}^{-2} \mathrm{yr}^{-1}$ (negative fluxes represent net uptake from the atmosphere) is still a reasonably accurate estimate of contemporary peatland $\mathrm{C}$ accumulation rates in the Northern Hemisphere. This has been reaffirmed by a number of recent measurements in Canada and Sweden (Roulet et al. 2007, Nilsson et al. 2008). However, there is some suggestion that net ecosystem exchange (NEE) values, defined as $\mathrm{CO}_{2}$ exchange between the land surface and the atmosphere (the balance between photosynthesis and total ecosystem respiration commonly measured using eddy covariance), for British and UK peats may be higher than Gorham's (1991) estimate. Values of -40 to $-70 \mathrm{~g} \mathrm{C} \mathrm{m}^{-2} \mathrm{yr}^{-1}$ (Cannell et al. 1993) and $-102 \pm 47 \mathrm{~g} \mathrm{C} \mathrm{m}^{-2} \mathrm{yr}^{-1}$ (Janssens et al. 2005) have been reported in the literature. Other estimates suggest a lower range of values (-32.5 and $-13.1 \mathrm{~g} \mathrm{C} \mathrm{m}^{-2} \mathrm{yr}^{-1}$ ) that vary with respect to micro-scale changes in surface peatland topography (Clymo \& Pearce 1995).
One of the fundamental differences in temperate UK peatlands compared to more northern boreal and subarctic peatlands is climate; the UK has a more variable maritime climate in contrast to the continental climate associated with areas such as the Canadian and Siberian peatlands. Consequently, UK peatlands are dominated by extensive areas of blanket bog, which is at the warmer and wetter end of the climate envelope associated with northern peatlands (Wieder \& Vitt 2006). This implies that variables such as precipitation, frequency of storm events and drought are more likely to have a significant year-on-year and seasonal effect on flux rates in UK peatlands compared to those developed under more continental climates. Blanket peats in the UK are therefore unusual in a global context as the climate is generally wetter and they are often developed in upland areas (with steeper hydrological gradients); peatland development in the UK during the Holocene is also thought to be strongly linked to past human impact as a direct result of early forest clearance leading to wetter soil conditions (Charman 2002, Simmons 2003).

UK peatlands are often actively managed in ways which can alter the net ecosystem C balance (NECB) (Chapin et al. 2006). Land management includes the widespread use of drainage, prescribed fire, peat extraction, grazing, fertilisation and liming (Holden et al. 2007). The effects of these management practices on plant community productivity and composition are significant, potentially resulting in a net increase in $\mathrm{C}$ losses to the atmosphere and the fluvial system. Currently, one of the most widespread peatland management interventions in the UK is drain blocking (Holden et al. 2007); this aims to reverse the drainage process by restoring the water table to natural levels, with positive effects for biodiversity, habitat, water and $\mathrm{C}$ storage. UK peatlands and their associated vegetation and surface waters have been significantly impacted by changes in nitrogen (N) and sulphur (S) deposition (e.g. Ferguson et al. 1978, Skiba et al. 1989, C. D. Evans et al. 2006). There is currently widespread concern about the impact of global warming in the northern regions and the potential impact on the C pool (e.g. Frey \& Smith 2005). These effects are closely linked to changes in seasonal snow cover, temperature, precipitation patterns and the length of the growing season, all of which will have consequences for $\mathrm{C}$ storage in peatlands.

The combination of climatic variability and the effects of various direct and indirect anthropogenic threats make UK peatlands particularly vulnerable to change. However, whether these effects are having an impact on the peatland $\mathrm{C}$ balance is unclear. A major UK research challenge is to measure, attribute and predict rates of change in $\mathrm{C}$ budgets and to provide the scien- 
tific basis for optimally managing $\mathrm{C}$ sequestration in peatlands for climate mitigation alongside other essential ecosystem services. In the present study, we review the current understanding of the contemporary peatland C balance from: (1) short-term high resolution monitoring and (2) long-term paleoecological studies. We also identify key research areas in need of future development required to provide the necessary evidence for optimally managing long-term peatland $\mathrm{C}$ pools.

\section{APPROACHES AND METHODOLOGY}

The $\mathrm{C}$ balance of any terrestrial ecosystem is measured by quantifying the fluxes (amount of $\mathrm{C}$ lost or gained) of all known $\mathrm{C}$ species into and out of a specific landscape unit of known size (e.g. Billett et al. 2004). For $C$, this is particularly challenging because of the range of dissolved (dissolved organic $\mathrm{C}$ [DOC], dissolved inorganic $\mathrm{C}[\mathrm{DIC}])$, gaseous $\left(\mathrm{CO}_{2}, \mathrm{CH}_{4}\right)$ and particulate (particulate organic C [POC]) species as well as the number of different flux pathways (landatmosphere exchange, water-atmosphere exchange, precipitation, runoff) involved (see Hope et al. 1994). Gas exchange with the atmosphere also varies spatially within a landscape unit (McNamara et al. 2008, Dinsmore et al. 2009b). All fluxes vary spatially and temporally on a daily, seasonal and annual basis. This suggests that $5+$ yr data sets are needed to reduce uncertainty, obtain reliable long-term trends and unpick more subtle decadal changes in the NECB.

The ability to combine flux measurements, which in the past have often been made separately by different groups of researchers, is key to determining the NECB (Chapin et al. 2006). Whilst it is well beyond the scope of this review to describe all the methods in detail, Fig. 1 summarises the approaches involved which are described in the paper. NEE is the largest and most variable flux term and is commonly measured using an eddy covariance system mounted on a flux tower with a $\mathrm{CO}_{2}$ analyser measuring concentrations at short time intervals (see Foken \& Nappo 2008 for a full description of the method). The tower samples a time-variant flux footprint, the orientation and size of which is controlled by the height of the flux tower, wind velocity and direction (e.g. Hargreaves et al. 2003, Roulet et al.
2007). Most flux towers typically sample areas of $\sim 1 \mathrm{~km}^{2}$ over distances of 0.25 to $1.5 \mathrm{~km}$. The eddy covariance system has also been used to measure $\mathrm{CH}_{4}$ fluxes continuously (Hargreaves \& Fowler 1998); recent advances in instrumentation mean that it will now be possible to make these measurements more routinely in the field. Chambers can also be used to measure land-atmosphere gas exchange of both $\mathrm{CO}_{2}$ and $\mathrm{CH}_{4}$ within fixed areas of $<0.5 \mathrm{~m}^{2}$. The method, which has been used and reviewed extensively in the literature (e.g. Livingstone \& Hutchinson 1995), is attractive because it is cheap, flexible and can be used to examine the role of specific vegetation communities and microtopographic features on greenhouse gas fluxes, capturing the smaller scale variability missed by the flux towers (McNamara et al. 2008, Dinsmore et al. 2009b). However, chambers can introduce significant methodological artefacts into measured flux rates due to physical and biological disturbance of the microenvironment; natural small-scale variability also means that upscaling to large catchment areas is problematic. The best approach to measuring landatmosphere $\mathrm{CO}_{2}$ and $\mathrm{CH}_{4}$ exchange is therefore to use both chambers and flux towers; this allows independently measured fluxes at different scales to be combined. Alternatively, there are a number of modelling approaches used to estimate NEE, examples of which are described in some of the following case studies.

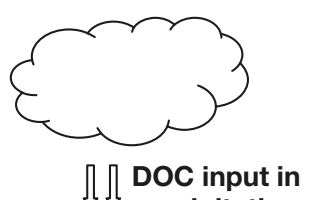
precipitation

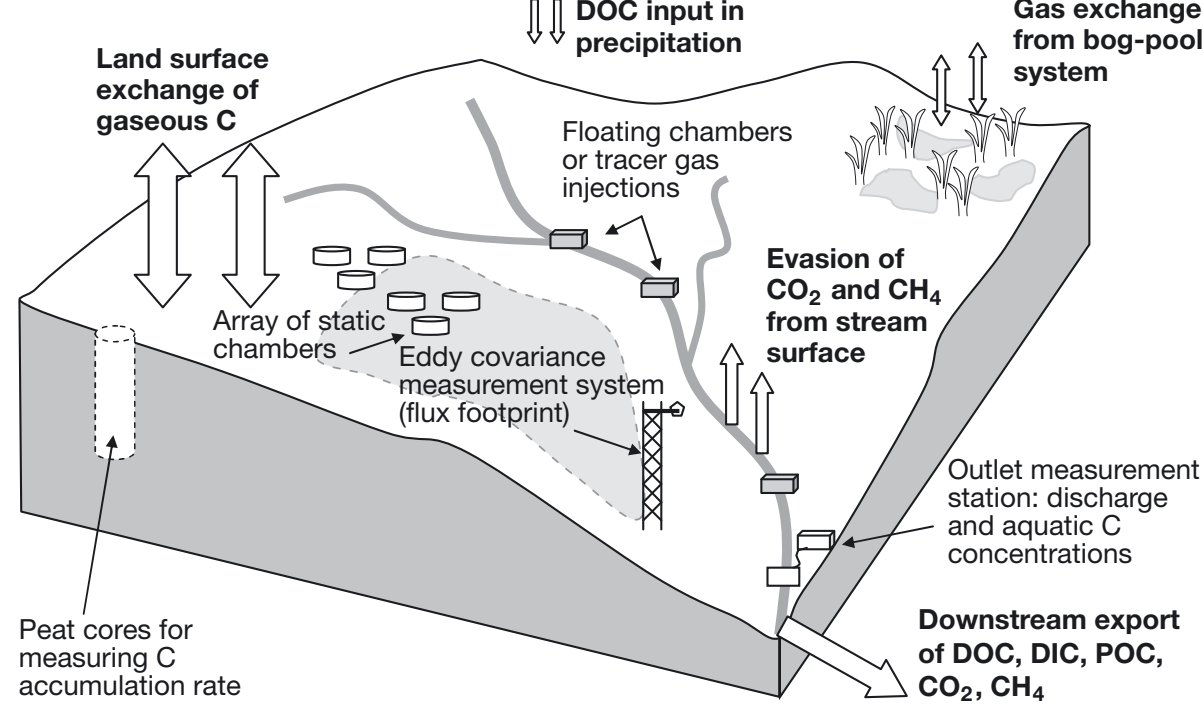

Fig. 1. Approaches and methods used to measure catchment $\mathrm{C}$ balance and accumulation rates in peatlands. The size of the arrows represents the relative magnitude of the various $\mathrm{C}$ fluxes. DOC: dissolved organic carbon; DIC: dissolved inorganic carbon; POC: particulate organic carbon 
Measuring fluxes of $\mathrm{C}$ leaving the catchment via the aquatic pathway is generally easier since the flux is unidirectional (export) and, provided the catchment is watertight and the boundaries accurately delineated, the lateral losses occur at one point, the catchment outlet. This is a critical but often overlooked point; watertightness is evaluated by: (1) a judgement based upon detailed knowledge of the underlying geology and/or (2) comparison of annual catchment evapotranspiration rate and water balance (precipitation input minus runoff) (Cerny et al. 1994) A sampling regime that captures short-term temporal changes in streamwater hydrochemistry and continuous discharge measurement (often through a control structure such as a flume or weir) provides the basis for measuring year-on-year fluxes in DOC, POC, DIC and dissolved gases $\left(\mathrm{CO}_{2}\right.$ and $\mathrm{CH}_{4}$ ). Since peatland streams are often supersaturated with respect to $\mathrm{CO}_{2}$ and $\mathrm{CH}_{4}$ (Dawson et al. 1995, Billett $\&$ Moore 2008), the aquatic system also provides a conduit for exchange of dissolved gases between the water surface and the atmosphere (the degassing or evasion flux). Although relatively few measurements have been made, it is known that the flux varies both spatially and temporally (Hope et al. 2001), with the greatest fluxes associated with a high degree of supersaturation and water turbulence (Billett \& Moore 2008); hence it is difficult to quantify accurately at a landscape scale. This has led to a range of often indirect approaches to estimating what appears to be a significant unknown flux term in the context of the overall peatland $\mathrm{C}$ balance. Inputs of dissolved $\mathrm{C}$ also occur in precipitation. Although the amounts are generally small compared to the magnitude of land-atmosphere gaseous exchange and aquatic losses, they should be considered and included in a complete catchment $\mathrm{C}$ balance.

Few studies in the UK (and globally) include a complete set of directly measured flux $\mathrm{C}$ terms, a notable exception being that from the Auchencorth Moss peatland in SE Scotland (Dinsmore et al. 2010). Some of the longest year-on-year studies are from outside the UK, most notably in Canada (Roulet et al. 2007) and Sweden (Nilsson et al. 2008). Whilst this situation is changing in the UK with new initiatives like the Centre for Ecology and Hydrology (CEH) carbon catchments (www.ceh.ac.uk/sci_programmes/Carbon ExchangeattheCatchmentScale.htm), which will help improve full quantification of the peatland $\mathrm{C}$ balance, most studies to date still rely on a combination of measured and estimated values in the absence of a full suite of data. A number of studies estimate fluxes (e.g. respiration or decomposition) from established relationships with water table or temperature (e.g. Worrall et al. 2003). Others gap-fill the NECB by using literature values for some of the smaller flux terms like DOC inputs in precipitation or $\mathrm{CH}_{4}$ emissions (Billett et al.
2004, Worrall et al. 2009). Until these best estimate approaches can be compared to fully quantified budgets, the uncertainty associated with these methods will remain unknown.

Longer term peat (and C) accumulation rates can be measured throughout the Holocene period using peat cores. These paleoenvironmental methods allow contemporary accumulation rates to be compared to those of the recent past and provide context for direct measurement of $\mathrm{C}$ budgets via NEE and monitoring of aquatic fluxes. Peatlands are one of the few ecosystems that preserve a record of their own development with the successive accumulation of material over decades to millennia. Estimates of long-term $\mathrm{C}$ accumulation rates have been made for a number of areas of the world, focusing primarily on millennial-scale C accumulation rates and changes (e.g. Mäkila 1997, Mäkila \& Moisanen 2007, Beilman et al. 2009). The data required for such estimates are $C$ density and age measurements from different depths of peat, the latter normally based on a series of radiocarbon ages. The same approach can also be used to estimate relative rates of $\mathrm{C}$ accumulation in near-surface peats by dating the last few decades, although the cost of radiocarbon dating this period is often prohibitive (see Hardie et al. 2007). Another technique for estimating recent peat ages is the use of short-lived radioisotopes such as ${ }^{210} \mathrm{~Pb}$; however, these are often problematic in peat and require validation with other markers (Oldfield et al. 1995). A relatively inexpensive technique that has been used in a number of palaeoenvironmental studies are counts of spheroidal carbonaceous particles (SCPs), which are markers of major changes in the level of pollution from high-temperature combustion of oil and coal over the past $150 \mathrm{yr}$. Three timemarkers are available for the UK (Rose et al. 1995), relating to: (1) the start of SCP deposition in the mid19th century, (2) the rapid take-off following widespread expansion of oil and coal-fired power stations in the 1950s and 1960s, and (3) a peak in SCPs in the mid1970 s before the introduction of clean burn technologies. The precise dates for these markers vary regionally, but the northwest of the UK, where most blanket peatlands occur, shows the same changes across the region (Rose \& Appleby 2005). The rapid take-off and peak levels are easier to detect than the start of the curve, and Rose \& Appleby (2005) use cumulative SCP curves prior to the peak instead of markers to improve comparisons between sites. Since raw SCP data were not available to us here, we use markers as the main reference points. The following set of 5 case studies provides a measure of the current state of knowledge of the C balance of UK peatlands and highlights future research challenges. Four are from sites with continuous monitoring data (Auchen- 
corth Moss, Moor House, Bleaklow, Conwy) (Fig. 2) and one is a collection of paleoenvironmental data from 3 locations across the UK (Laxford Bridge, Lochnagar, Butterburn Flow). Collectively they demonstrate the range of methods and approaches used, as well as highlighting the importance of individual fluxes in specific peatlands.

\section{PEATLAND C BALANCE AND FLUXES: CASE STUDIES}

\subsection{C balance of Auchencorth Moss (SE Scotland)}

Auchencorth Moss was the first UK peatland to combine measurements of land-atmosphere $\mathrm{C}$ exchange and aquatic $\mathrm{C}$ fluxes (Billett et al. 2004) to produce an assessment of whether the catchment was acting as a sink or source of $\mathrm{C}$. The measurements were made for

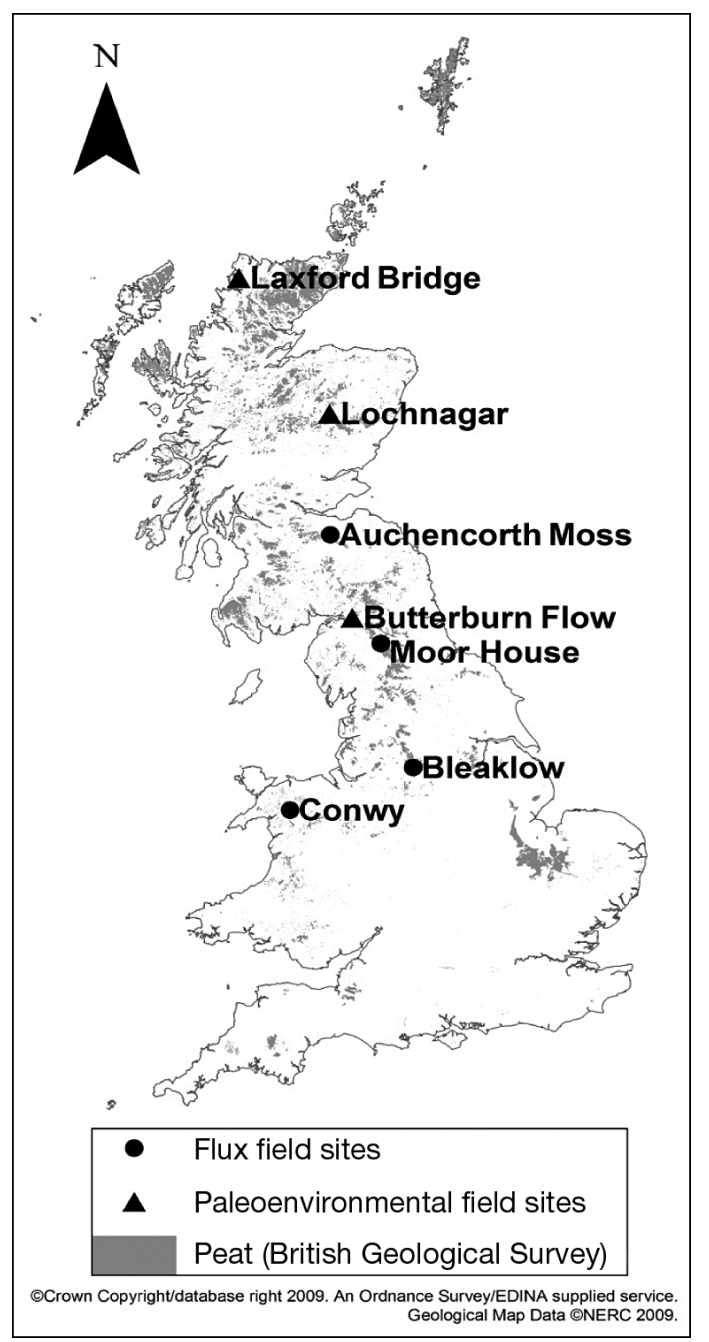

Fig. 2. Locations of the main study sites described in the text. Palaoenvironmental data is also cited from Moor House the period 1996-1998, and the overall conclusion was that the peatland was either acting as a $\mathrm{C}$ source or was C-neutral. Continuous long-term measurements of NEE have now been made since 2002 from an eddy covariance system (prior to 2002, NEE measurements were made discontinuously). In addition, aquatic $\mathrm{C}$ flux measurements for particulate, dissolved and gaseous $\mathrm{C}$ species have been made continuously since 2006 and the site is building a long-term record of $C$ import and export terms. Auchencorth Moss is one of $4 \mathrm{CEH}$ carbon catchments which have recently been set up to quantify the long-term changes in the yearon-year $\mathrm{C}$ balance in peatlands by measuring all the important $\mathrm{C}$ flux terms. The other sites are located in Forsinard (N Scotland), Moor House (N England) and Conwy (N Wales).

Auchencorth Moss $\left(55^{\circ} 47^{\prime} \mathrm{N}, \quad 03^{\circ} 14^{\prime} \mathrm{W}\right.$; altitude range 249 to $300 \mathrm{~m}$ ) is a $3.4 \mathrm{~km}^{2}$ low-lying ombrotrophic peatland (85\% peat) developed on glacial till which lies above an Upper Carboniferous/Lower Devonian sequence of sandstones and shaly sandstones with minor limestone, mudstone, coal and clay layers (Billett et al. 2004). The majority of the catchment is used for lowintensity sheep grazing with a small area of peat extraction in the southwest corner. The vegetation consists of a patchy mix of grasses and sedges covering a primarily Sphagnum base layer on a typical peatland hummock/ hollow microtopography; mean annual precipitation (2002-2008) and temperature (1971-2000) are $1155 \mathrm{~mm}$ and $10^{\circ} \mathrm{C}$, respectively (Drewer et al. 2010) The catchment drains through a series of natural tributaries and overgrown (>100 yr old) drainage ditches into the main stream, the Black Burn.

Net ecosystem $C$ balances, which have now been produced on 2 separate occasions for Auchencorth Moss covering the 2-yr periods 1996-1998 and 20062008, show that the 2 largest flux terms are NEE and aquatic $\mathrm{C}$ loss (Table 2). The data show significant variability in the NEE value, which can only partially be explained by differences and improvements in protocols used for the calculation of NEE. The second most significant flux term, loss of $\mathrm{C}$ in the aquatic system, is dominated by DOC export in the Black Burn. In both the 1996-1998 and 2006-2008 studies, the DOC loss term is relatively consistent, with POC, DIC and free $\mathrm{CO}_{2}$ making relatively minor contributions to total aquatic $\mathrm{C}$ loss. On both occasions, evasion of $\mathrm{CO}_{2}$ from the water surface to the atmosphere was the second most important flux involving the aquatic system. Quantifying the flux is complex since evasion is known to vary spatially and temporally within catchments (Billett \& Moore 2008, Dinsmore et al. 2010). The larger evasion flux value in 2006-2008 reflects recent developments and improvements in upscaling approaches, which allow a better catchment-scale estimate of $\mathrm{CO}_{2}$ 
Table 2. Carbon fluxes into (positive) and out (negative) of Auchencorth Moss peatland summed to produce the net ecosystem C balance (all values in $\mathrm{g} \mathrm{C} \mathrm{m}^{-2} \mathrm{yr}^{-1}$ ). 1996-1998 and 2006-2008 data are from Billett et al. (2004) and Dinsmore et al. (2010), respectively; both publications contain a full description of the methods used. NEE: net ecosystem exchange; DOC: dissolved organic carbon; POC: particulate organic carbon; DIC: dissolved inorganic carbon

\begin{tabular}{|lcc|}
\hline Flux term & $1996-1998$ & $2007-2008$ \\
\hline NEE & -27.8 & -115 \\
DOC (precipitation) & $-3.1^{\mathrm{a}}$ & $-1.4^{\mathrm{a}}$ \\
$\mathrm{CH}_{4}$ emission & $+4.1^{\mathrm{a}}$ & +0.3 \\
Aquatic $\mathrm{CO}_{2}$ evasion & +4.6 & +12.7 \\
Aquatic $\mathrm{DOC}$ & +26.9 & +25.4 \\
Aquatic $\mathrm{POC}$ & $+1.4^{\mathrm{a}}$ & +3.6 \\
Aquatic $\mathrm{DIC}$ & +1.2 & +0.7 \\
Aquatic $\mathrm{CO}_{2}$ & +0.9 & +1.3 \\
Aquatic $\mathrm{CH}_{4}$ & $+<0.01$ & $+<0.01$ \\
Net C balance & +8.3 & -72.4 \\
a Estimated value & & \\
\hline
\end{tabular}

exchange between the water surface and the atmosphere (Dinsmore et al. 2010). Methane emissions from the land surface, measured using chambers in 20062008, are unusually low at Auchencorth Moss compared to other peatland sites (Dinsmore et al. 2009b, Drewer et al. 2010). This is likely to be because site conditions (low water table, absence of surface bogpool systems) do not encourage methane production. Peat mesocosm experiments in peats derived from the site also confirm the low methane emissions from Auchencorth Moss (Dinsmore et al. 2009a).

At this early stage in the long-term measurement of the overall $\mathrm{C}$ balance at Auchencorth Moss it can be concluded that significant year-on-year variability in NEE has the largest single impact on the NECB. The aquatic system is a significant and less variable $C$ export term. The most recent measurements suggest the peatland is acting as a major sink for $\mathrm{C}$, with an accumulation rate of $\sim 72 \mathrm{~g} \mathrm{C} \mathrm{m}^{-2} \mathrm{yr}^{-1}$ during the period 2006-2008.

\subsection{C budgets and fluxes at Moor House (N England)}

Moor House is the most extensively studied of all UK peatland sites, with research on upland ecology dating back to the 1950s. The mass balance approach was first used to quantify fluxes of several key macronutrients ( $\mathrm{Ca}, \mathrm{Na}, \mathrm{K}, \mathrm{P}$ and $\mathrm{N}$ ) in Rough Sike as early as the 1960s (Crisp 1966). Measurement of aquatic C concentrations and fluxes is a more recent development, although long-term records still date back to 1993. Routine measurements now take place on 3 catchments: Rough Sike $\left(0.83 \mathrm{~km}^{2}\right)$ and Cottage Hill
Sike $\left(0.20 \mathrm{~km}^{2}\right)$, both subcatchments of Trout Beck $\left(11.4 \mathrm{~km}^{2}\right)$. There have also been 2 attempts to estimate complete C budgets for the Moor House catchment (Worrall et al. 2003, 2009). Here we present data on several of the important fluxes from the Moor House area and demonstrate the importance of withincatchment hotspots of gaseous $\mathrm{C}$ emissions and the impact of upland land management on $\mathrm{C}$ budget, as well as describe some of the indirect techniques which can be used to support direct measurements in the development of the NECB.

The Moor House National Nature Reserve is located in the North Pennines of England (54 $65^{\prime} \mathrm{N}, 2^{\circ} 45 \mathrm{~W}$; altitude 450 to $893 \mathrm{~m}$ ). It includes an extensive area of blanket peat ranging in thickness from 0.4 to $5 \mathrm{~m}$ (Heal \& Smith 1978) developed on a thick layer of impermeable glacial boulder clay overlying a sequence of Carboniferous limestone, sandstone and shale. The most common vegetation species are Calluna vulgaris (L.), Eriophorum vaginatum (L.), E. angustifolium (L.), Rubus chamaemorus (L.), Pleurozium schreberi (Brid.) and Sphagnum capillifolium (Ehrh). Mean annual temperature is $5.3^{\circ} \mathrm{C}$; mean annual rainfall (at $550 \mathrm{~m}$ ) is 1982 mm (Holden \& Adamson 2001).

The overall $\mathrm{C}$ balance of the largest catchment at Moor House (Trout Beck; $11.4 \mathrm{~km}^{2}$ ) has been the focus of a recent paper by Worrall et al. (2009). Using both direct measurements (e.g. aquatic DOC fluxes) and indirect methods (e.g. estimating net ecosystem respiration and primary productivity using empirical relationships established between chamber measurements, soil temperature and water table), the authors have compiled a complete peatland $\mathrm{C}$ budget over the period 1993 to 2005. During the $13 \mathrm{yr}$ study period the peatland acted as a net $\mathrm{C}$ sink ( -20 to $-91 \mathrm{~g} \mathrm{C} \mathrm{m}^{-2} \mathrm{yr}^{-1}$ ) with an average of $-56 \mathrm{~g} \mathrm{C} \mathrm{m}^{-2} \mathrm{yr}^{-1}$. The DOC flux at the outlet of catchment varied from +10.3 to $+25.3 \mathrm{~g} \mathrm{C} \mathrm{m}^{-2} \mathrm{yr}^{-1}$. These values are consistent with those described for Auchencorth Moss, but are quite distinct from the early values reported for Moor House of a net sink of $-15.4 \pm 11.9 \mathrm{~g} \mathrm{C} \mathrm{m}^{-2} \mathrm{yr}^{-1}$ (Worrall et al. 2003). These differences can be ascribed to developments in and understanding of methods for estimating $\mathrm{C}$ budgets.

The smallest of the study catchments, Cottage Hill Sike, developed wholly on blanket peat, is the site of one of the $\mathrm{CEH}$ carbon catchments. Stream water has been sampled weekly by the Environmental Change Network at the outlet of Cottage Hill Sike from late 1992 onwards; these data have been used to develop a 15 yr record of DOC fluxes (Fig. 3). Water samples were analysed for DOC following published protocols (Sykes \& Lane 1996). As continuous long-term discharge monitoring only began at Cottage Hill Sike in 2007, proxy estimates of discharge were obtained by proportional downscaling of catchment area using 


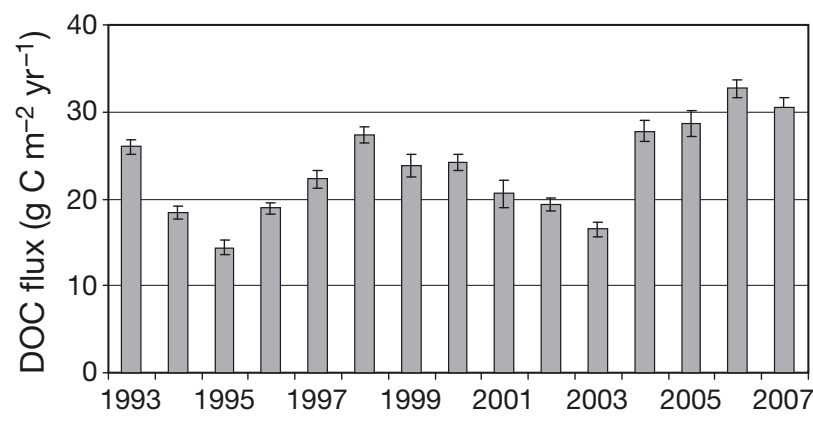

Fig. 3. Annual variation in dissolved organic carbon (DOC) flux in Cottage Hill Sike. Error bars represent 95\% confidence limits

continuous 15 min discharge measurements made since 1992 at the nearby Trout Beck weir. Gaps in the discharge record were filled using empirical relationships between rainfall and discharge (Clark 2005). Annual load was estimated using Method 5 (Walling \& Webb 1985, Littlewood 1992), which uses longterm flow data and (in this case) weakly concentration measurements; confidence limits for fluxes were determined using methods described in Hope et al. (1997a).

Annual DOC fluxes varied from 14.3 (1995) to 32.7 (2006) with an overall mean of $23.4 \mathrm{~g} \mathrm{C} \mathrm{m}^{-2} \mathrm{yr}^{-1}$ (Fig. 3). Although there appears to be no clear statistical trend, the 4 most recent years (2004-2007) are the years with the highest annual downstream fluxes and also the years with the highest recorded and flow-weighted DOC concentrations. Previous analysis of the flux data from Cottage Hill Sike has shown that the greatest DOC fluxes were observed during years with greatest rainfall (Clark et al. 2007). Although increased rainfall and discharge is often associated with decreased DOC concentrations in peat drainage waters (e.g. Bishop \& Pettersson 1996), the decline in the annual flowweighted mean concentration in years of high rainfall was small compared to the magnitude of the increase in rainfall and overall C export (Clark et al. 2007). Integrated analysis of soil and stream water concentrations in Cottage Hill Sike have shown a close coupling between the supply of DOC from near surface soil water ( -1 to $-10 \mathrm{~cm}$ depth) and DOC transported through the stream water network (Clark et al. 2005, Clark et al. 2008). On the basis of these data alone, it is difficult to determine whether increased DOC fluxes during years with the greatest rainfall were simply due to increased leaching and transport of DOC from soil to stream and/or increased supply of DOC during wet years due to a decline in consumption and respiration of DOC within the soil. The degree to which aquatic and gaseous peatland $\mathrm{C}$ fluxes are coupled or disconnected has important implications for understanding the future response of the whole $\mathrm{C}$ budget to changes in climate, especially rainfall.
Numerous gullies intersect the blanket peats at Moor House, characterised by shallower peat depths, increased water percolation and a distinctive vegetation cover. A study by McNamara et al. (2008) showed significant variation in ecosystem $\mathrm{CO}_{2}$ respiration and net $\mathrm{CH}_{4}$ fluxes from typical plant-peat systems at Moor House located in dendritic drainage gullies and adjacent blanket peat during the growing season (June-August). Typically, Eriophorum spp., Sphagnum spp. and mixed grasses occupied gullies, while Calluna vulgaris occurred in adjacent blanket peat. Gross ecosystem (i.e. plant and soil) $\mathrm{CO}_{2}$ respiration was highest in the areas of Eriophorum spp. $\left(0.18 \pm 0.04 \mathrm{~g} \mathrm{CO}_{2}-\mathrm{C} \mathrm{m}^{-2} \mathrm{~h}^{-1}\right) \mathrm{com}-$ pared to those with Sphagnum spp. $\left(0.09 \pm 0.01 \mathrm{~g} \mathrm{CO}_{2}-\mathrm{C}\right.$ $\left.\mathrm{m}^{-2} \mathrm{~h}^{-1}\right)$, mixed grasses $\left(0.09 \pm 0.02 \mathrm{~g} \mathrm{CO}_{2}-\mathrm{C} \mathrm{m}^{-2} \mathrm{~h}^{-1}\right)$ and C. vulgaris $\left(0.05 \pm 0.02 \mathrm{mg} \mathrm{CO}_{2}-\mathrm{C} \mathrm{m}^{-2} \mathrm{~h}^{-1}\right)$. Measurements of the net $\mathrm{CH}_{4}$ flux showed higher fluxes when Eriophorum spp were present $\left(0.002 \pm 0.001 \mathrm{~g} \mathrm{CH}_{4}-\mathrm{C}\right.$ $\left.\mathrm{m}^{-2} \mathrm{~h}^{-1}\right)$ compared to Sphagnum spp. $(0.0006 \pm 0.0004 \mathrm{~g}$ $\left.\mathrm{CH}_{4}-\mathrm{C} \mathrm{m}^{-2} \mathrm{~h}^{-1}\right)$, mixed grasses $\left(0.0001 \pm 0.0001 \mathrm{~g} \mathrm{CH}_{4}-\mathrm{C}\right.$ $\mathrm{m}^{-2} \mathrm{~h}^{-1}$ ) and C. vulgaris (negligible fluxes). A GIS approach was applied to calculate the contribution of gullies to landscape-scale greenhouse gas fluxes and it was estimated that, although gullies occupied only $9.3 \%$ of the total peatland surface, they accounted for 95.8 and $21.6 \%$ of the net $\mathrm{CH}_{4}$ and gross $\mathrm{CO}_{2}$ respiratory fluxes, respectively. These findings confirmed that landscape features such as gullies were hotspots of greenhouse gas emissions and emphasised the importance of including flux measurements from spatially less significant areas of the catchment in the overall assessment of the $\mathrm{C}$ balance (e.g. Dinsmore et al. 2009b). In another study of vegetation management, Ward et al. (2007) found that both peatland burning and grazing increased net $\mathrm{CO}_{2}$ fluxes. The greatest effects were seen in the burning treatment, where the observed NEE increased by up to $40 \%$ in the summer months (May-August), with NEE equal to $-38 \mathrm{~g}$ $\mathrm{CO}_{2}-\mathrm{C} \mathrm{m}^{-2}$ in controls compared with $-85 \mathrm{~g} \mathrm{CO}_{2}-\mathrm{C} \mathrm{m}^{-2}$ in burned treatments. Collectively, these recent studies emphasise the importance of plant-soil interactions as key regulators of peatland ecosystem greenhouse gas fluxes at Moor House, and show that changes in plant community composition and/or productivity play an important role in determining the magnitude of gaseous C fluxes.

The extensive gully network at Moor House is also a reflection of the degree of erosion that the site has experienced in the past. Unlike the more actively eroding systems of the southern Pennines, the Moor House gullies have experienced significant natural revegetation of gully floors. M. Evans \& Warburton (2005) demonstrated that gully floor revegetation causes a significant reduction in the particulate flux from the gullies to the stream system. For the Rough Sike sub-catchment this was equivalent to a reduction 
in POC flux from 45 to $18 \mathrm{~g} \mathrm{C} \mathrm{m}^{-2} \mathrm{yr}^{-1}$ over the period 1960-1998 (M. Evans et al. 2006). This example of change in the peatland landscape demonstrates the effect it has on gully land-atmosphere C (McNamara et al. 2008) and aquatic (POC) fluxes.

\subsection{C fluxes at Conwy (N Wales)}

The Migneint is one of the largest areas of blanket bog in Wales, designated as a Special Area of Conservation (SAC). The northern part of the SAC forms the headwaters of the River Conwy, and has been intensively studied as one of the $4 \mathrm{CEH}$ carbon catchments. Annual precipitation and temperature are $2200 \mathrm{~mm}$ and $5.6^{\circ} \mathrm{C}$, respectively, whilst the underlying geology comprises Ordovician mudstones with areas of basic and acid volcanic tuffs. Within a $1 \mathrm{~km}^{2}$ peat-dominated subcatchment (415 to $487 \mathrm{~m})$, the Nant y Brwyn $\left(55^{\circ} 47^{\prime} \mathrm{N}, 03^{\circ} 14^{\prime} \mathrm{W}\right)$ fluvial DOC, POC and inorganic solute concentrations have been monitored fortnightly since 2006, augmented by a continuous stream monitoring system measuring conductivity, $\mathrm{pH}$, coloured dissolved organic matter and turbidity by fluorescence. Static chamber gas fluxes have been measured on a monthly basis in areas of blanket bog and acid grassland on mineral soil since 2007. An eddy covariance system for $\mathrm{CO}_{2}$ flux measurement was installed in 2009, along with an expanded static chamber network covering a wider range of soil/vegetation types within the catchment. Chemical measurements are supported by an automatic weather station, discharge and water table gauges.

The Conwy study is at an early stage, and a full catchment $\mathrm{C}$ budget cannot yet be reliably constructed. A year of monthly static chamber data suggest mean $\mathrm{CH}_{4}$ emissions of the order of $6 \mathrm{mg} \mathrm{C} \mathrm{m}^{-2} \mathrm{yr}^{-1}$ from an area of Calluna-Sphagnum blanket bog, with a negligible net flux from the acid grassland. This is considerably higher than the value for Auchencorth Moss and Moor House. At the catchment scale ( 80\% blanket bog), this equates to a net $\mathrm{CH}_{4}$ emission of around $5 \mathrm{mg}$ $\mathrm{C} \mathrm{m}^{-2} \mathrm{yr}^{-1}$. However, this estimate does not yet include measured data from potential hotspots such as gullies and riparian wetlands (McNamara et al. 2008, Dinsmore et al. 2009b), which might be expected to lead to an increase in the overall catchment flux.

Fluvial C fluxes have been estimated based on 2-yr volume-weighted mean concentrations (October 2006 to September 2008) and annual runoff. DOC was measured directly, POC by loss-on-ignition $\left(3 \mathrm{~h}\right.$ at $550^{\circ} \mathrm{C}$ ) and DIC $\left(\mathrm{HCO}_{3}^{-}\right.$plus dissolved $\left.\mathrm{CO}_{2}\right)$ was estimated from stream $\mathrm{pH}$ and Gran alkalinity, following the method of Neal (1988). Estimated annual DOC flux for the 2-yr period was $19.3 \mathrm{~g} \mathrm{C} \mathrm{m}^{-2} \mathrm{yr}^{-1}$, POC $0.9 \mathrm{~g} \mathrm{C} \mathrm{m}^{-2}$ $\mathrm{yr}^{-1}$ and DIC $0.6 \mathrm{~g} \mathrm{C} \mathrm{m}^{-2} \mathrm{yr}^{-1}$. These data suggest that (as in other catchments) DOC forms the major fluvial C flux from the Conwy site, and that fluvial export comprises a significant component of the overall catchment C budget.

Conwy is the only study site for which parallel DOC measurements exist for a lake. Llyn Conwy drains a small, peat-dominated catchment adjacent to the Nant y Brwyn, and has a water residence time of 1 yr. DOC concentrations have been measured for peats and podzol O horizons, based on monthly sampling at 0 to $10 \mathrm{~cm}$ depth using multiple Rhizon ${ }^{\mathrm{TM}}$ samplers. Annual DOC flux estimates (Fig. 4) provide an insight into the transport and fate of DOC through the soil-water continuum. They suggest that DOC production from the peat acrotelm and podzol $\mathrm{O}$ horizons are similar, but that around $50 \%$ of this DOC is lost during transport to the catchment outlet. Considerable retention (and subsequent mineralisation) of DOC is likely within podzol mineral horizons, but given the small areal extent of podzols within the Nant y Brywn, it appears that DOC retention and/or mineralisation may also be occurring either during lateral transport or immediately following emergence of DOC-rich water into the stream channel. Rapid in-stream DOC removal was also inferred from downstream concentration decreases at Moor House (Gibson et al. 2009). Based on a comparison of the Conwy stream and lake output fluxes, it appears that a further $40 \%$ of DOC may be removed by in-lake processing. The fate of this DOC (i.e. oxidation to $\mathrm{CO}_{2}$ versus burial in sediments) represents a significant uncertainty in the $\mathrm{C}$ budget of catchments containing lakes (e.g. Jonsson et al. 2007, Battin et al. 2009).

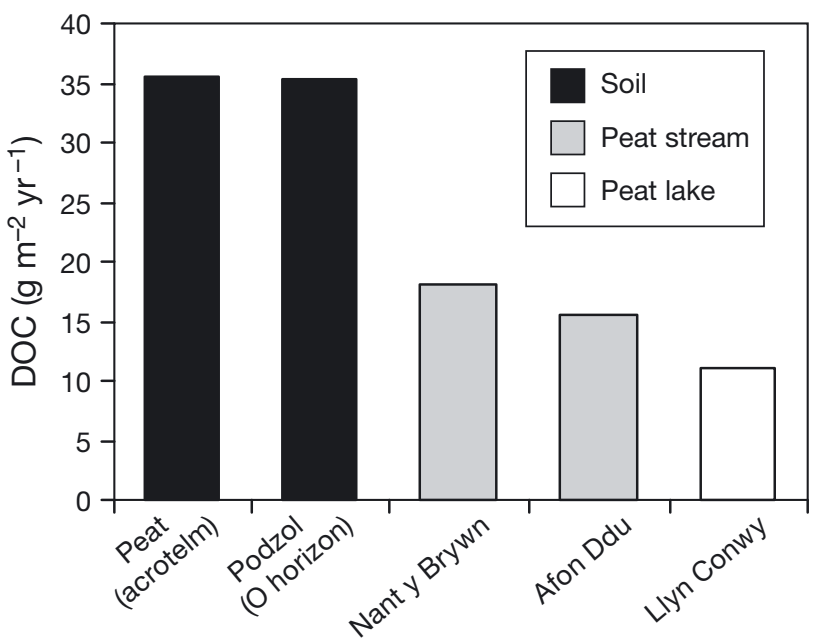

Fig. 4. Estimated dissolved organic carbon (DOC) fluxes (g C $\mathrm{m}^{-2} \mathrm{yr}^{-1}$ ) from the surface horizons of 2 soil types, 2 peat streams and from a lake draining a peat catchment, from October 2007 to September 2008. Note that the estimate for Llyn Conwy is per unit land area within the catchment (i.e. allowing for no DOC production within the lake itself) 


\subsection{C fluxes on Bleaklow (N England)}

A long history of land management, atmospheric deposition and climate change characterises the Bleaklow Plateau (S. Pennines) as one of the most impacted peatland areas in the UK, affected by significant $\mathrm{C}$ loss, particularly by erosion. The plateau ( $\left.53^{\circ} 27^{\prime} \mathrm{N}, 1^{\circ} 51^{\prime} \mathrm{W}\right)$ is an area of extensive deep peat with altitude ranging from 468 to $630 \mathrm{~m}$ above sea level; mean annual rainfall is $1554 \mathrm{~mm}$ (Daniels et al. 2008) and mean annual temperature $7.1^{\circ} \mathrm{C}$. The area has suffered from extensive erosion and dissection due to heavy grazing, visitor pressure, wildfire and a legacy of atmospheric deposition of metals and acidifying pollutants. In April 2003 the plateau experienced a wildfire that lead to the devegetation of $5.5 \mathrm{~km}^{2}$ of the peat soils in the area. As a result of this and other impacts, the whole Bleaklow area has become the focus of extensive restoration activity (drain blocking and deliberate revegetation).

The extensive dissection of the plateau by gully erosion and consequent exposure of bare peat on gully walls and by wildfire scars means that rates of POC production by surface erosion are high. Measured erosion rates on gully walls are $\sim 0.034 \mathrm{~m} \mathrm{yr}^{-1}$ (M. Evans et al. 2006). Assuming a typical peat density of $0.1 \mathrm{~g} \mathrm{~cm}^{-3}$ and a $\mathrm{C}$ content of $50 \%$, this equates to a particulate $\mathrm{C}$ loss of $136 \mathrm{~g} \mathrm{C} \mathrm{m}^{-2} \mathrm{yr}^{-1}$ based on a realistic drainage density of $20 \mathrm{~km} \mathrm{~km}^{-2}$ and an average gully depth of $2 \mathrm{~m}$ (M. Evans \& Lindsay 2010). This POC production rate does not, however, equate to POC flux at the catchment scale, because of in-catchment deposition of POC in gully floors and on floodplains, and because of the potential transformation of POC to DOC in the fluvial system (M. Evans et al. 2006, Pawson 2008, Pawson et al. 2008). Measured catchment POC fluxes available from a range of small catchments across the plateau are summarised in Table 3.

Measured POC fluxes vary from $3.4 \mathrm{~g} \mathrm{C} \mathrm{m}^{-2} \mathrm{yr}^{-1}$ in a small uneroded catchment to over $90 \mathrm{~g} \mathrm{C} \mathrm{m}^{-2} \mathrm{yr}^{-1}$ in severely eroding systems. Flux is controlled not only by sediment production from bare surfaces, but also by the connectivity of those surfaces to the stream drainage network. The lower flux values reported for Torside Clough (Table 3) are consistent with observations by Rothwell et al. (2007) that the eroded areas of this catchment are poorly linked to the stream system. Connectivity in eroding peatland systems is strongly controlled by the balance between erosion and revegetation (M. Evans \& Warburton 2005, 2007). Although there is evidence of some active revegetation of the Bleaklow Plateau (Crowe et al. 2008), gully erosion is widespread and covers over $25 \%$ of the area (M. Evans \& Lindsay 2010). Values of POC flux in the higher range of the reported catchments are therefore more typical of the system. This implies that, unlike intact systems discussed by Hope et al. (1997b), the fluvial $\mathrm{C}$ flux of the Bleaklow Plateau is dominated by $\mathrm{C}$ in the solid phase. For comparison, Pawson et al. (2008) reported a DOC flux from the Upper North Grain catchment of $18.5 \mathrm{~g} \mathrm{C} \mathrm{m}^{-2} \mathrm{yr}^{-1}$ and $\mathrm{O}^{\prime}$ Brien et al. (2008) estimated fluxes ranging from 6 to $18 \mathrm{~g} \mathrm{C} \mathrm{m}^{-2} \mathrm{yr}^{-1}$ from 3 catchments on Bleaklow where there had been recent management change.

The dominance of the POC flux within the fluvial $\mathrm{C}$ budget of eroding systems emphasises the importance of a major knowledge gap in the understanding of peatland $\mathrm{C}$ cycling, namely the fate of $\mathrm{POC}$ in the fluvial system. There is some evidence that a proportion of POC is converted to both the gaseous and dissolved phases during transport (M. Evans et al. 2006, Pawson et al. 2008, Pawson 2008), suggesting that consideration of the POC flux is pertinent to assessments of atmospherically active $\mathrm{C}$ flux. The magnitude of this effect and the transformation processes require further research.

Other research on the Bleaklow Plateau has focussed not just on the fluvial system, but on producing whole $\mathrm{C}$ budgets from specific catchment areas using a combination of direct and indirect methods. The 2 sites were chosen as controls against which success of re-

Table 3. Measured particulate organic carbon (POC) fluxes from Bleaklow Plateau catchments

\begin{tabular}{|lccll|}
\hline Catchment & $\begin{array}{c}\text { Area } \\
\left(\mathrm{km}^{2}\right)\end{array}$ & $\begin{array}{c}\text { POC flux } \\
\left(\mathrm{g} \mathrm{C} \mathrm{m}^{-2} \mathrm{yr}^{-1}\right)\end{array}$ & Source & Notes \\
\hline Upper North Grain & 0.38 & 95.7 & $\begin{array}{l}\text { M. Evans et al. (2006) } \\
\text { Pawson et al. (2008) }\end{array}$ & $\begin{array}{l}\text { Severe gully erosion } \\
\text { Severe gully erosion } \\
\text { Calculated from data in Rothwell (2006) } \\
\text { based on 70\% organic content }\end{array}$ \\
$\begin{array}{l}\text { Torside Clough } \\
\text { Unnamed micro- catchment } \\
\text { near Bleaklow summit }\end{array}$ & 0.0007 & 92.5 & M. G. Evans unpubl. data & Bare peat catchment \\
$\begin{array}{l}\text { Unnamed micro- catchment } \\
\text { near Snake summit }\end{array}$ & 0.005 & 3.4 & M. G. Evans unpubl. data & Uneroded catchment \\
Lady Clough & 1.33 & 44.8 & Pawson (2008) & \\
\hline
\end{tabular}


vegetation could be judged thought to be typical of the vegetation on the Bleaklow Plateau. One site (PD) was dominated by Eriophorum spp., the second control (WC) was dominated by the shrubs Vaccinium spp. and Empetrum spp. The catchment areas for PD and WC were 0.005 and $0.02 \mathrm{~km}^{2}$, respectively. The methods used to develop overall catchment $\mathrm{C}$ budgets of PD and WC were:

(1) Plot-scale measurements using piezometers (water table), chambers (gas fluxes) and erosion pins. Sites were sampled from December 2006; data presented here are for the first $2 \mathrm{yr}$ of the study.

(2) Catchment-scale measurements of fluvial DOC fluxes based on weekly samples collected in 2008. The method used for estimating excess dissolved $\mathrm{CO}_{2}$ in runoff from fresh soil water samples drawn from piezometers in described in Worrall et al. (2009). POC fluxes losses (surface lowering) are measured from annual measurements of nests of erosion pins (12 pins per plot). At the catchment scale, POC flux was measured directly through runoff sampling using rising stage and automatic water samplers.

(3) Surface exchange of $\mathrm{CO}_{2}$ and $\mathrm{CH}_{4}$ was measured using a closed chamber method (see Worrall et al. 2009).

(4) Interpolation and extrapolation methods are used to upscale and estimate $\mathrm{C}$ budgets. For example, NEE is estimated using calibrated equations for soil respiration and primary productivity. For a full description of the approach and the calculated errors see Worrall et al. (2009).

The combined flux measurement shows strong differences between the 2 sites, with one appearing as a sink and the other a source (Table 4). The main differences in the flux terms, which appear to produce this shift in the NECB, are a weaker drawdown of $\mathrm{CO}_{2}$ from the atmosphere (relatively lower primary productivity and higher respiration rates) and much higher fluvial (POC and DOC) fluxes. This could be due to the difference in vegetation type between the 2 control sites or it could represent the greater proportion of bare soil under shrub vegetation. In conclusion, research on the Bleaklow Plateau suggests that this part of the UK is characterised by unusually high POC fluxes. Clearly management can have a significant effect on peatland $C$ balance in both the short and the long term.

\subsection{Historical rates of $\mathrm{C}$ accumulation}

We compiled the published SCP data from England and Scotland to provide estimates of peatland $\mathrm{C}$ accumulation for different time periods (Table 5). Although there are many other sites with SCP data available in the literature, most of these only used SCPs to provide
Table 4. Summary of the individual fluxes and the overall estimated $\mathrm{C}$ budgets $\left(\mathrm{g} \mathrm{C} \mathrm{m}^{-2} \mathrm{yr}^{-1}\right)$ for the 2 study catchments (PD and WC) on Bleaklow Plateau. DOC: dissolved organic carbon; POC: particulate organic carbon; NEE: net ecosystem exchange; nd: not determined

\begin{tabular}{|ccccccc|}
\hline Site & $\begin{array}{c}\text { Fluvial } \\
\text { DOC }^{\mathrm{a}}\end{array}$ & $\begin{array}{c}\text { Fluvial } \\
\text { POC }\end{array}$ & NEE & $\mathrm{CH}_{4}$ & $\begin{array}{c}\text { Dissolved } \\
\mathrm{CO}_{2}\end{array}$ & $\begin{array}{c}\text { Carbon } \\
\text { balance }\end{array}$ \\
\hline Year 1 & & & & & & \\
PD & $13.0^{\mathrm{a}}$ & 1.9 & -92 & 0.7 & 1.3 & -75 \\
WC & $95.6^{\mathrm{a}}$ & nd & -44 & 0.7 & 1.3 & nd \\
Year 2 & & & & & & \\
PD & $13.0^{\mathrm{a}}$ & 3.4 & -120 & 0.7 & 1.3 & -102 \\
WC & $95.6^{\mathrm{a}}$ & 37.7 & -65 & 0.7 & 1.3 & 70 \\
a Mean 2-yr value & & & & \\
\hline
\end{tabular}

dates for palaeoenvironmental reconstructions (e.g. Chambers et al. 1999), and relatively few sites have bulk density and/or C content data available, which are needed to transform depths and dated layers to net $\mathrm{C}$ accumulation rates. There are sufficient data to provide some insights into $\mathrm{C}$ accumulation rates over the last $150 \mathrm{yr}$ on peatlands in the UK.

To assemble these data we took published depth estimates for the 3 major changes in SCPs (start, takeoff and peak) and bulk density data to estimate peat accumulation as dry mass per year since the mid-19th century, the mid-20th century and the late-1970s, together with accumulation rates between these time intervals. Regional curves from Rose \& Appleby (2005) were used to estimate ages from unpublished SCP data (Table 5). Dry mass accumulation was converted into $\mathrm{C}$ accumulation using loss-on-ignition (LOI) and \% $\mathrm{C}$ data. Where only bulk density data were available, we assumed $98 \%$ LOI and C content of $50 \%$ organic matter. LOI was measured using methods based on those of Allen (1989).

Calculated rates of $\mathrm{C}$ accumulation varied between 35.1 and $209.1 \mathrm{~g} \mathrm{C} \mathrm{m}^{-2} \mathrm{yr}^{-1}$. The highest rates generally occur in the uppermost peat layers, as would be expected due to the incomplete decay of organic matter in the acrotelm. However, temporal trends within individual sites suggest that despite incomplete decay in near-surface material, rates may have slowed (Lochnagar) or remained the same (Laxford Bridge) since the 1970s. Consistent with likely trends from incomplete decay, rates are generally lower for the mid-19th to mid-20th century period (39.6 to $73.1 \mathrm{~g} \mathrm{C}$ $\mathrm{m}^{-2} \mathrm{yr}^{-1}$ ), but again rates at Lochnagar are comparable with the late 20th century, which could be interpreted as a recent reduction in productivity or more rapid decay of recent organic matter. Differences between sites might be related to local context, especially vegetation composition and hydrology. The highest rates of $\mathrm{C}$ accumulation occur in the raised mire sites (Butter- 


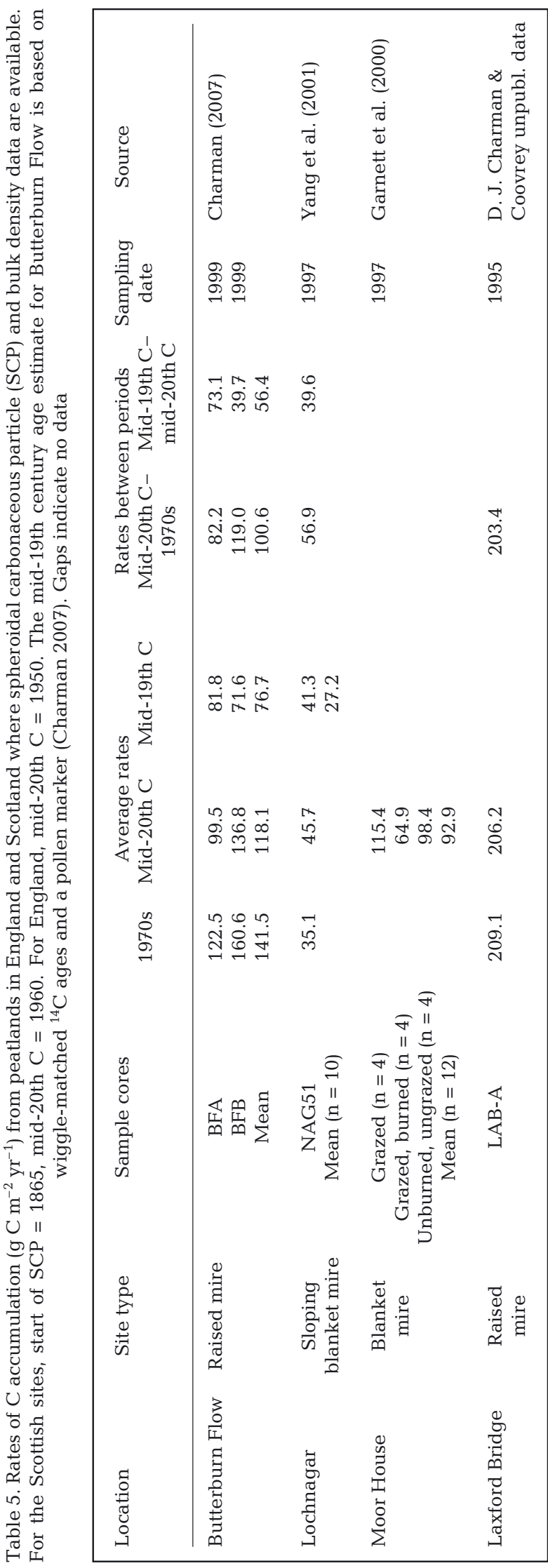

burn Flow and Laxford Bridge) with rates $>100 \mathrm{~g} \mathrm{C}$ $\mathrm{cm}^{-2} \mathrm{yr}^{-1}$ since the mid-20th century. These sites are generally wetter with Sphagnum-dominated vegetation. However, the Moor House blanket mire has similar rates in areas unaffected by burning, although it might be expected to have lower Sphagnum presence and a drier surface. A wider range of accumulation rates was found for this site by Hardie et al. (2007) who reported a range of 20 to $125 \mathrm{~g} \mathrm{C} \mathrm{m}^{-2} \mathrm{yr}^{-1}$ since ca. 1950 based on the presence of post-bomb ${ }^{14} \mathrm{C}$ in peat. However, the precision of the estimates by Hardie et al. (2007) was low because sample depth resolution was only $4 \mathrm{~cm}$, leading to wide variations in the range of estimated $\mathrm{C}$ accumulation rates for individual cores (e.g. 19.6 to $60 \mathrm{~g} \mathrm{C} \mathrm{m}^{-2} \mathrm{yr}^{-1}$ for a single core). This emphasises the need for high resolution (samples of $1 \mathrm{~cm}$ thickness or less) for stratigraphic estimates of $\mathrm{C}$ accumulation, to enable differences between sites to be identified. The lowest rates are at Lochnagar, a high altitude, low net primary productivity, sloping blanket mire site more likely dominated by vascular plants and with a relatively dry surface due to more rapid runoff.

The estimates of $\mathrm{C}$ accumulation presented here are subject to a number of potential errors and uncertainties, principally related to dating. Despite extensive work on SCP profiles in lakes dated independently with ${ }^{210} \mathrm{~Pb}$, the absolute ages of changes in SCPs may only be accurate to within $\pm 15 \mathrm{yr}$ (Rose \& Appleby 2005), although relative age estimates may be much better within individual regions. Furthermore, the precision of the age estimate also depends on the sampling precision down core. However, the scale of the uncertainty is unlikely to alter the main trends and differences between site types, and the longer-term absolute rates of $\mathrm{C}$ accumulation from the mid-19th century. Further data are clearly required to understand the relationship between $\mathrm{C}$ accumulation, site type and management regime (e.g. Garnett et al. 2000), as well as to evaluate any possible regional patterns. For example, it might be expected that $\mathrm{C}$ accumulation is lower in regions at the limit of peat distribution or in less favourable topographic situations. These regions are also those most likely to be vulnerable to future change. It should be remembered that apparent rates of $\mathrm{C}$ accumulation in recent peat do not reflect the $\mathrm{C}$ balance of the entire peat column. The deeper peat continues to decay, albeit at a much slower rate (Clymo 1984). The total C balance is thus partly dependent on losses at depth as well as gains in the near surface. Large changes in hydrological or temperature regime may lead to significant shifts in C balance of deeper as well as near-surface peat. This highlights an important difference between the catchment-based NECB approach and the use of peat cores to measure recent changes in $\mathrm{C}$ accumulation rates. 


\section{DISCUSSION}

\subsection{UK peatland $C$ balance: uncertainty and measurement techniques}

The question 'is the $\mathrm{C}$ balance (or rate of $\mathrm{C}$ accumulation) in UK peatlands changing?' has provided focus for this review. It highlights the importance of reducing levels of uncertainty in flux measurements and applying the best methods and approaches. Contemporary flux data gives a snapshot in time with annual reporting of UK peatland $\mathrm{C}$ budgets at a relatively early stage compared to sites in Canada (Roulet et al. 2007) and Sweden (Nilsson et al. 2008). Generally, all sites showed NEE to be the largest and most variable flux term both temporally (from continuous measurements) and spatially with respect to vegetation cover, gullying and surface wetness. For example, year-on-year NEE fluxes measured at Mer Bleue (Canada) using eddy covariance varied from -2 to $-112 \mathrm{~g} \mathrm{C} \mathrm{m}^{-2} \mathrm{yr}^{-1}$, with a $6 \mathrm{yr}$ mean $\left( \pm \mathrm{SE}\right.$ ) of $-40.2 \pm 40.5 \mathrm{~g} \mathrm{C} \mathrm{m}^{-2} \mathrm{yr}^{-1}$ (Roulet et al. 2007). The long-term (2003-2008) mean NEE for Auchencorth Moss in SE Scotland is $-74 \pm 22 \mathrm{~g} \mathrm{C}$ $\mathrm{m}^{-2} \mathrm{yr}^{-1}$, with year-on-year variability ranging from a small source of $\mathrm{CO}_{2}$ in $2003(+20)$ to a significant sink in in 2008 (-136) (Dinsmore et al. 2010). In all cases the potential errors in the annual calculation of NEE values are large ( 30 to $100 \%$ of the overall flux). Clearly as more data become available the controls on longterm temporal variability in NEE will become easier to interpret and model, leading to a reduction in uncertainty. Studies have shown that it is possible to estimate NEE from other factors (Worrall et al. 2009), although no comparison of direct versus indirect methods of measuring and/or estimating this key flux term have, to date, been made.

In the UK, as well as in other countries, there has been greater emphasis on aquatic $\mathrm{C}$ fluxes compared to continuous land-atmosphere exchange monitoring, which is more expensive and technically more challenging. Whilst aquatic fluxes are important, they are generally smaller. The $15 \mathrm{yr}$ DOC flux record at Cottage Hill Sike shows that the flux is annually less variable (Fig. 3) than NEE and levels of uncertainty are significantly lower. The DOC flux data from all of the study sites (catchment sizes 0.2 to $3.35 \mathrm{~km}^{2}$ ) also point to a level of consistency, with fluxes ranging from 18.5 to $26.9 \mathrm{~g} \mathrm{C} \mathrm{m}^{-2} \mathrm{yr}^{-1}$. Fluxes from smaller (0.005 to $0.05 \mathrm{~km}^{2}$ ) catchments are more variable (Table 4), hence our data suggest that levels of uncertainty in aquatic flux measurements can be significantly reduced by working at scales $>0.1 \mathrm{~km}^{2}$. The level of uncertainty in aquatic flux measurements will also be reduced by the increased use of sensors to continuously measure concentrations of $\mathrm{C}$ species like DOC and $\mathrm{CO}_{2}$ (Dinsmore \& Billett 2008, Koehler et al. 2009, Johnson et al. 2010).

All of these fluxes are mediated spatially with respect to vegetation type and land management practices. Processes affecting POC export differ, as these exports are greatest in disturbed landscapes affected by erosion. An optimal monitoring strategy for measuring the annual peatland $\mathrm{C}$ balance requires continuous flux tower measurements of $\mathrm{CO}_{2}$ and $\mathrm{CH}_{4}$ exchange; continuous, weekly or biweekly spot sampling for DOC (associated with continuous discharge), a method for estimating the evasion flux; and, ideally, eventbased POC sampling. The importance of individual flux terms (and the need to measure them) will vary from catchment to catchment in response to the degree of disturbance and the amount and type of precipitation.

Other methods have also been used to address the question of peatland stability. Isotopic evidence $\left({ }^{14} \mathrm{C}\right)$ can be used to identify whether older $\mathrm{C}$ is being released into the drainage system, a potential indicator of mobilisation of deep peat $\mathrm{C}$ which has been stored and remained immobile for 100s or 1000s of years. Measurements of DOC $-{ }^{14} \mathrm{C}$ from UK peat catchments suggest that the majority is derived from recently fixed plant material rather than older peat (C. D. Evans et al. 2007, Palmer et al. 2001). On the other hand, ${ }^{14} \mathrm{C}$ measurements of evaded $\mathrm{CO}_{2}$ suggest that significantly older $\mathrm{C}$ is being released in some peatland streams, some of which may be geogenic rather than biogenic in origin (Billett et al. 2007).

\subsection{Role of the aquatic flux pathway}

This group of case studies highlights the importance of including aquatic $\mathrm{C}$ fluxes in peatland $\mathrm{C}$ budgets. DOC fluxes in the range of 19 to $27 \mathrm{~g} \mathrm{C} \mathrm{m}^{-2} \mathrm{yr}^{-1}$ are typical of UK peatlands and significant in the context of the overall budget; POC losses are more variable, but can reach up to $100 \mathrm{~g} \mathrm{C} \mathrm{m}^{-2} \mathrm{yr}^{-1}$ in eroding systems. In addition, recent measurements of $\mathrm{CO}_{2}$ evasion from the water surface of peatlands to the atmosphere (Hope et al. 2001, Dinsmore et al. 2010) show that at the catchment scale, fluxes are significant (up to $14.1 \mathrm{~g}$ $\mathrm{C} \mathrm{m}^{-2} \mathrm{yr}^{-1}$ ) and comparable to those of DOC. The combined DOC, POC and $\mathrm{CO}_{2}$ evasion fluxes represent a significant loss term in the peatland $\mathrm{C}$ budget and one that is clearly sensitive to change. In UK blanket peats, the rapid rate of hydrological flushing clearly favours fluvial C export over other C loss pathways. This review highlights the significant rates of POC removal in the aquatic system from the eroding peatlands on Bleaklow, and evidence of past high rates from Moor House (M. Evans \& Warburton 2005) emphasises the importance of maintaining physical stability in peat- 
lands. As UK peatlands become increasingly climatestressed over the next century (Clarke et al. this Special), the risk of enhanced erosion is likely to extend to other peatland systems. A full assessment of the potential impact of reported high POC fluxes also requires further research on the fate of $\mathrm{POC}$ in the fluvial environment. Transformation of POC to DOC and oxidation of POC from river floodplains has the potential to impact the greenhouse gas budgets of peatlands as well as individual peatland $C$ budgets (Pawson 2008). The rates and controls of these transformations is an important gap in our current knowledge of fluvial C fluxes.

Whilst contemporary $\mathrm{C}$ budgeting involves measuring all the flux terms, a more selective approach would be to identify a key flux pathway that shows less shortterm (annual or seasonal) variability and, therefore, is more likely to show long-term underlying change. Since the aquatic system and the export rates of various forms of $\mathrm{C}$ are controlled by a variety of (often interconnected) within-catchment processes, stream export of $\mathrm{C}$ may be a better integrator (or signal) of change within the catchment. Interestingly, the typical annual export of DOC for peatland streams (19 to $27 \mathrm{~g}$ $\mathrm{C} \mathrm{m}^{-2} \mathrm{yr}^{-1}$ ) is comparable to Gorham's (1991) estimate of the contemporary $\mathrm{C}$ accumulation rate for northern peatlands ( $23 \mathrm{~g} \mathrm{C} \mathrm{m}^{-2} \mathrm{yr}^{-1}$ ). We could therefore hypothesise that change in accumulation rate might be connected to and be reflected in changes to the release of $\mathrm{C}$ into the peatland aquatic system. As long-term data on DOC fluxes are more readily available and easier to monitor, this approach may be more pragmatic. However, before this assumption can be made, we need to establish to what extent the aquatic (DOC) and gaseous $C$ fluxes (NEE) are coupled. Does an increase in DOC flux equate to an increase in $\mathrm{C}$ storage? Or does an increase in DOC flux result in a lower gaseous flux, as less $C$ is mineralised in situ? Detailed longterm monitoring data over a range of climatic conditions will be required to unravel these factors.
There are, however, many uncertainties in relating DOC flux to other components of the $\mathrm{C}$ cycle. In particular, ${ }^{14} \mathrm{C}$ data, indicating a predominantly recent origin for DOC, imply that DOC may be more closely related to primary production than to peat decomposition. Additionally, there is evidence that other factors, notably decreases in acid deposition, have altered the mobility of DOC within upland soils, leading to increasing aqueous DOC losses (Monteith et al. 2007). For peat catchments specifically, fewer long-term data are available from which to assess whether fluxes have increased. Data for Moor House are somewhat equivocal (Fig. 3), while the other sites considered here have insufficiently long records to evaluate trends. However, longer records (1988-2008) for the 4 peat-dominated catchments in the UK Acid Waters Monitoring Network all show clear increases in DOC concentration (C. D. Evans et al. 2005). In the absence of clear hydrological changes over the same period (C. D. Evans et al. 2006), an approximate rate of flux increase can be obtained by multiplying the rate of annual DOC increase by mean runoff. These calculations (Table 6), which also include the Cottage Hill Sike data, suggest that DOC fluxes have risen by between 0.3 and $0.6 \mathrm{~g} \mathrm{C} \mathrm{m}^{-2} \mathrm{yr}^{-1}$ in the period 2003-2007. If this was applied to a $20 \mathrm{yr}$ period (1988-2008) it would be equivalent to a total increase in the annual flux of 5.5 to $10.5 \mathrm{~g} \mathrm{~m}^{-2}$. One of the rivers (Etherow) drains the northern part of the Bleaklow Plateau and the increase here can be compared to the high POC flux estimates given earlier. Overall, it appears that DOC losses from UK peatlands may have increased considerably over the last $20 \mathrm{yr}$. However, the controls on DOC leaching are complex, and the nature of inter-linkages between DOC flux and other components of the $\mathrm{C}$ balance remains obscure. Therefore, we do not (at present) believe that fluvial DOC flux can be used as a reliable indicator of changes in the overall peatland $\mathrm{C}$ balance.

Table 6. Estimated dissolved organic carbon concentrations, fluxes and rate of change at 5 UK peat-dominated catchments for which long-term data are available. Mean concentration and mean flux refer to the period 2003-2007

\begin{tabular}{|c|c|c|c|c|c|c|}
\hline Site & Period & $\begin{array}{l}\text { Mean runoff } \\
\quad\left(\mathrm{m} \mathrm{yr}^{-1}\right)\end{array}$ & $\begin{array}{c}\text { Mean } \\
\text { concentration } \\
\left(\mathrm{mg} \mathrm{l}^{-1}\right)\end{array}$ & $\begin{array}{l}\text { Rate of concen- } \\
\text { tration change } \\
\left(\mathrm{mg} \mathrm{l}^{-1} \mathrm{yr}^{-1}\right)\end{array}$ & $\begin{array}{c}\text { Mean } \\
\text { flux } \\
\left(\mathrm{g} \mathrm{C} \mathrm{m}^{-2} \mathrm{yr}^{-1}\right)\end{array}$ & $\begin{array}{c}\text { Rate of flux } \\
\text { change } \\
\left(\mathrm{g} \mathrm{C} \mathrm{m}^{-2} \mathrm{yr}^{-1}\right)\end{array}$ \\
\hline $\begin{array}{l}\text { Cottage Hill Sike } \\
\text { (N Pennines) }\end{array}$ & 1993-2007 & 1.55 & 18.93 & 0.32 & 29.2 & 0.54 \\
\hline $\begin{array}{l}\text { River Etherow } \\
\text { (S Pennines) }\end{array}$ & 1988-2007 & 1.44 & 9.23 & 0.42 & 10.5 & 0.48 \\
\hline $\begin{array}{l}\text { Loch Tinker } \\
\text { (C Scotland) }\end{array}$ & 1988-2007 & 1.86 & 6.81 & 0.20 & 12.7 & 0.37 \\
\hline $\begin{array}{l}\text { Beaghs Burn } \\
\text { (N Ireland) }\end{array}$ & 1988-2007 & 1.22 & 15.44 & 0.43 & 18.8 & 0.52 \\
\hline $\begin{array}{l}\text { Coneyglen Burn } \\
\text { (N Ireland) }\end{array}$ & 1988-2007 & 1.10 & 10.08 & 0.25 & 11.1 & 0.27 \\
\hline
\end{tabular}




\subsection{Peatland $\mathrm{C}$ management}

Optimal management of soil $\mathrm{C}$ and its losses has recently been extensively reviewed (Dawson \& Smith 2007). The case studies presented here demonstrate that peatland management and change clearly affects annual fluxes, but how do these changes affect the overall $\mathrm{C}$ balance or pool? To put Holocene rates of $\mathrm{C}$ accumulation and contemporary flux rates into context, Billett et al. (2006) estimated the length of time it would take to release all the soil organic $C$ from a small peatland catchment in NE Scotland based on rates of annual export of organic $\mathrm{C}$ in the aquatic system alone. Assuming no further $\mathrm{C}$ sequestration from the atmosphere, it would take $\sim 4300$ yr for the catchment to be depleted of its store of soil organic $\mathrm{C}$. This demonstrates the magnitude of the stored $\mathrm{C}$ pool in relation to contemporary flux rates. A similar calculation for the impacted peatland catchments on the Bleaklow Plateau based on POC losses alone gives a figure of $\sim 1150 \mathrm{yr}$. Therefore, considering the changes in climate predicted (Clark et al. this Special), there is a millennial-scale period for managing declining peatlands, even if annual drawdown of $\mathrm{CO}_{2}$ from the atmosphere ceased. This has important implications for peatland management in the UK.

\section{CONCLUSIONS AND FUTURE RESEARCH CHALLENGES}

We are at a relatively early stage in making yearon-year integrated $\mathrm{C}$ fluxes measurements in UK peatlands, with few complete data sets to explore long-term trends and drivers of change. The contemporary measurements that exist from 2 large catchments suggest that current accumulation rates $\left(-56\right.$ to $\left.-72 \mathrm{~g} \mathrm{C} \mathrm{m}^{-2} \mathrm{yr}^{-1}\right)$ may be lower than those seen over the last $150 \mathrm{yr}$ in peat cores ( -35 to $-209 \mathrm{~g} \mathrm{C} \mathrm{m}^{-2} \mathrm{yr}^{-1}$ ). This conclusion may well change in the future as longer-term data sets become available. There are also considerable between-site differences in rates derived from peat cores and a number of fundamental differences in approaches. Our current stage of knowledge therefore suggests that UK peatlands continue to operate as a long-term sink for $\mathrm{C}$ (as they have done since the end of the last ice age) unless they are affected by high management or climatic pressures. Although this may change in the future, the ability to manage peatland $\mathrm{C}$ stores is evident and should be a high priority for stakeholders.

Currently we have a rough understanding of the time scale over which we expect flux terms to vary, and the environmental factors that influence these, but our knowledge of the magnitude of these changes is incomplete. UK peatlands are managed, and management intensity varies from location to location. Site- based evidence suggests that management, like burning, can reduce the $\mathrm{C}$ sink strength, but we are unable to quantify the resulting flux changes at a national scale. Alternatively, interventions like drain blocking are able to increase the sink strength of peatlands. We also know that large areas of blanket peats have been exposed to a long-history of atmospheric pollution (particularly $\mathrm{S}$ and $\mathrm{N}$ ); however, we do not know what the impact of this has been on long-term $\mathrm{C}$ turnover (e.g. by lowering the C:N ratio) or the individual flux terms. More detailed process-level research suggests that the role of plant community composition is important as a determinant of ecosystem scale $\mathrm{C}$ fluxes. The potential to use this understanding in the future development of mechanistic models of peatland $\mathrm{C}$ dynamics holds considerable promise as a means to reduce uncertainty in model estimates.

Our understanding of interactions between local and regional pressures on the contemporary $\mathrm{C}$ balance is incomplete, as is our understanding of how these pressures may interact with future climate change to increase the net fluxes of $\mathrm{C}$ from these systems. High quality, reliable flux data, with empirical understanding of the factors controlling these fluxes is essential to underpin the modelling work aimed at upscaling contemporary flux measurements spatially and temporally, and under future climate change scenarios.

There have been a number of recent demands for improved understanding and assessment of the sourcesink status of UK peatlands to inform policy, as environmental stewardship moves from a single resource focussed on exploitation for food production to a more holistic ecosystem services approach (Everard 2009). Attempts to quantify the $\mathrm{C}$ budget of UK peatlands are in their infancy and the short-term nature of these data sets is currently a weakness. The growing interest in managing $\mathrm{C}$ in the context of ecosystem services as a viable climate mitigation strategy suggests that there is a real need for a coherent, unified approach underpinned by scientific research based on long-term, sitebased monitoring networks.

Acknowledgements. The research presented here has been supported by a range of sources, in particular the UK Natural Environment Research Council. J.M.C. acknowledges the support of the Environment Agency (Science Project SC070036). D.J.C. thanks H. Yang for providing the raw data for the published plots in Yang et al. (2001) to enable calculation of $\mathrm{C}$ accumulation rates for Lochnagar.

\section{LITERATURE CITED}

Allen SE (1989) Chemical analysis of ecological materials. Blackwell Scientific Publications, Oxford

Battin TJ, Luyssaert S, Kaplan LA, Aufdenkampe AK, Richter A, Tranvik LJ (2009) The boundless carbon cycle. Nat 


\section{Geosci 2:598-600}

Beilman DW, MacDonald GM, Smith LC, Reimer PJ (2009) Carbon accumulation in peatlands of West Siberia over the last 2000 years. Global Biogeochem Cycles 23:GB1012 doi:10.1029/2007GB003112

Billett MF, Moore TR (2008) Supersaturation and evasion of $\mathrm{CO}_{2}$ and $\mathrm{CH}_{4}$ in surface waters at Mer Bleue Peatland, Canada. Hydrol Process 22:2044-2054

Billett MF, Palmer SM, Hope D, Deacon C and others (2004) Linking land-atmosphere-stream carbon fluxes. Global Biogeochem Cycles 18:GB1024 doi:10.1029/2003GB002058

Billett MF, Deacon C, Palmer SM, Dawson JJC, Hope D (2006) Connecting organic carbon in streamwater and soils in a peatland catchment. J Geophys Res 111:G02010 doi: 10.1029/2005JG000065

Billett MF, Garnett MH, Harvey F (2007) UK peatland streams release old carbon dioxide to the atmosphere and young dissolved organic carbon to rivers. Geophys Res Lett 34:L23401 doi:10.1029/2007GL031797

Bishop K, Pettersson C (1996) Organic carbon in the boreal spring flood from adjacent subcatchments. Environ Int 22:535-540

Bradley RI, Milne R, Bell J, Lilly A, Jordan C, Higgins A (2005) A soil carbon and land use database for the United Kingdom. Soil Use Manag 21:363-369

Cannell MGR, Dewar RC, Pyatt DG (1993) Conifer plantations on drained peatlands in Britain: A net gain or loss of carbon? Forestry 66:353-369

Cerny J, Billett MF, Cresser MS (1994) Element budgets. In: Moldan B, Cerny J (eds) Biogeochemistry of small catchments: a tool for environmental research. Wiley, London, p 189-205

Chambers FM, Mauquoy D, Todd PA (1999) Recent rise to dominance of Molinia caerulea in environmentally sensitive areas: new perspectives from palaeoecological data. J Appl Ecol 36:719-733

> Chapin FS III, Woodwell GM, Randerson JT, Rastetter EB and others (2006) Reconciling carbon-cycle concepts terminology and methods. Ecosystems 9:1041-1050

> Chapman SJ, Bell J, Donnelly D, Lilly A (2009) Carbon stocks in Scottish peatlands. Soil Use Manag 25:105-112

Charman DJ (2002) Peatlands and environmental change. John Wiley \& Sons, New York, NY

$>$ Charman DJ (2007) Summer water deficit variability controls on peatland water-table changes: implications for Holocene palaeoclimate reconstructions. Holocene 17:217-227

Clark JM (2005) Environmental controls on the production and export of dissolved organic carbon from an upland peat catchment. PhD thesis, University of Leeds, Leeds

> Clark JM, Chapman PJ, Adamson JK, Lane SN (2005) Influence of drought-induced acidification on the mobility of dissolved organic carbon in peat soils. Global Change Biol 11:791-809 doi:10.1111/j.1365-2486.2005.00937.x

> Clark JM, Lane SN, Chapman PJ, Adamson JK (2007) Exports of dissolved organic carbon from an upland peatland during storm events: implications for flux estimates. J Hydrol 347:438-447

Clark JM, Lane SN, Chapman PJ, Adamson JK (2008) Link between DOC in near surface peat and stream water in an upland catchment. Sci Total Environ 404:308-315

> Clymo RS (1984) The limits to peat bog growth. Proc R Soc Lond B 303:605-654

> Clymo RS, Pearce DME (1995) Methane and carbon dioxide production in, transport through, and efflux from a peatland. Philos Trans R Soc Lond A 351:249-259

$>$ Crisp DT (1966) Input and output of minerals for an area of Pennine moorland: the importance of precipitation, drainage, peat erosion and animals. J Appl Ecol 3:327-348

Crowe SK, Evans MG, Allott THE (2008) Geomorphological controls on the re-vegetation of erosion gullies in blanket peat: implications for bog restoration. Mires Peat 3:1-14

Daniels SM, Agnew CT, Allott TEH, Evans MG (2008) Water table variability and runoff generation in an eroded peatland, South Pennines, UK. J Hydrol 361:214-226

> Dawson JJC, Smith P (2007) Carbon losses from soil and its consequences for land-use management. Sci Total Environ 382:165-190

> Dawson JJC, Hope D, Cresser MS, Billett MF (1995) Downstream changes in free $\mathrm{CO}_{2}$ in an upland catchment in northeastern Scotland. J Environ Qual 24:699-706

> Dinsmore KJ, Billett MF (2008) Continuous measurement and modeling of $\mathrm{CO}_{2}$ losses from a peatland stream during stormflow events. Water Resour Res 44:W12417 doi:10.1029/ 2008WR007284

> Dinsmore KJ, Skiba UM, Billett MF, Rees RM (2009a) Effect of water table on greenhouse gas emissions from peatland mesocosms. Plant Soil 318:229-242

> Dinsmore KJ, Skiba U, Billett MF, Rees RM, Drewer J (2009b) Spatial and temporal variability in $\mathrm{CH}_{4}$ and $\mathrm{N}_{2} \mathrm{O}$ fluxes from a Scottish ombrotrophic peatland; implications for modelling and upscaling. Soil Biol Biochem 41:1315-1323

Dinsmore KJ, Billett MF, Skiba UM, Rees RM, Helfter C (2010) Role of the aquatic pathway in the carbon and greenhouse gas budgets of a peatland catchment. Glob Change Biol 16:2750-2762

Drewer J, Lohila A, Aurela M, Laurila T and others (2010) Comparison of greenhouse gas fluxes and nitrogen budgets from an ombrotrophic bog in Scotland and a pristine mire in Finland. Eur J Soil Sci 61:640-650

Evans CD, Monteith DT, Cooper DM (2005) Long-term increases in surface water dissolved organic carbon: observations, possible causes and environmental impacts. Environ Pollut 137:55-71

Evans CD, Chapman PJ, Clark JM, Monteith DT, Cresser MS (2006) Alternative explanations for rising dissolved organic carbon export from organic soils. Global Change Biol 12:2044-2053

> Evans CD, Freeman C, Cork LG, Thomas DN and others (2007) Evidence against recent climate-induced destabilisation of soil carbon from ${ }^{14} \mathrm{C}$ analysis of riverine dissolved organic matter. Geophys Res Lett 34:L07407 doi:10.1029/ 2007GL029431

Evans M, Lindsay J (2010) High resolution quantification of gully erosion in upland peatlands at the landscape scale. Earth Surf Proc Landf 35:876-886

Evans M, Warburton J (2005) Sediment budget for an eroding peat moorland catchment in northern England. Earth Surf Process Landf 30:557-577

Evans M, Warburton J (2007) The geomorphology of upland peat: pattern, process, form. Blackwell, Oxford

Evans M, Warburton J, Yang J (2006) Eroding blanket peat catchments: global and local implications of upland organic sediment budgets. Geomorphology 79:45-57

Everard M (2009) The business of biodiversity. WIT Press, Ashurst

Ferguson P, Lee JA, Bell JNB (1978) Effects of sulphur pollutants on the growth of Sphagnum species. Environ Pollut 16:151-162

Foken T, Nappo CJ (2008) Micrometeorology. Springer Verlag, Berlin

> Frey KE, Smith LC (2005) Amplified carbon release from vast West Siberian peatlands by 2100 . Geophys Res Lett 32:L09401 doi:10.1029/2004GL022025

Garnett MH, Ineson P, Stevenson AC (2000) Effects of burn- 
ing and grazing on carbon sequestration in a Pennine blanket bog, UK. Holocene 10:729-736

Gibson HS, Worrall F, Burt TP, Adamson JK (2009) DOC budgets of drained peat catchments: implications for DOC production in peat soils. Hydrol Process 23:1901-1911

Gorham E (1991) Northern peatlands: role in the carbon cycle and probable responses to climatic warming. Ecol Appl 1:182-195

Hardie SML, Garnett MH, Fallick AE, Rowland AP, Ostle NJ (2007) Spatial variability of bomb C-14 in an upland peat bog. Radiocarbon 49:1055-1063

> Hargreaves KJ, Fowler D (1998) Quantifying the effects of water table and soil temperature on the emission of methane from peat wetland at the field scale. Atmos Environ 32:3275-3282

- Hargreaves KJ, Milne R, Cannell MGR (2003) Carbon balance of afforested peatland in Scotland. Forestry 76: 299-317

Heal OW, Smith R (1978) The Moor House Program: introduction and site description. In: Heal OW, Perkins DF (eds) Production ecology of British moors and montane grasslands. Springer, Berlin, p 304-331

Holden J, Adamson JK (2001) Gordon Manley and the north Pennines. J Meteorol 26:329-333

Holden J, Shotbolt L, Bonn A, Burt TP and others (2007) Environmental change in moorland landscapes. Earth Sci Rev $82: 75-100$

Hope D, Billett MF, Cresser MS (1994) A review of the export of carbon in river water: fluxes and processes. Environ Pollut 84:301-324

Hope D, Billett MF, Cresser MS (1997a) Exports of organic carbon from two river systems in NE Scotland. J Hydrol 193:61-82

> Hope D, Billett MF, Milne R, Brown TAW (1997b) Exports of organic carbon in British rivers. Hydrol Process 11: 325-344

> Hope D, Palmer SM, Billett MF, Dawson JJC (2001) Carbon dioxide and methane oxidation evasion from a temperate peatland stream. Limnol Oceanogr 46:847-857

- Janssens IA, Freibauer A, Schlamadinger B, Ceulemans R and others (2005) The carbon budget of terrestrial ecosystems at country scale: a European case study. Biogeosciences 2:15-26

Johnson MS, Billett MF, Dinsmore KJ, Wallin M, Dyson K (2010) Direct and continuous measurement of dissolved carbon dioxide in freshwater aquatic systems - method and applications. Ecohydrology 3:68-78

> Jonsson A, Algesten G, Bergstrom AK, Bishop K, Sobek S, Tranvik LJ, Jansson M (2007) Integrating aquatic carbon fluxes in a boreal catchment carbon budget. J Hydrol 334: $141-150$

Koehler AK, Murphy K, Kiely G, Sottocornola M (2009) Seasonal variation of DOC concentration and annual loss of DOC from an Atlantic blanket bog in south western Ireland. Biogeochemistry 95:231-242

Littlewood IG (1992) Estimating contaminant loads in rivers: a review. Institute of Hydrology, Wallingford

Livingstone GP, Hutchinson GL (1995) Enclosure-based measurement of trace gas exchange: applications and sources of error. In: Matson PA, Harriss RC (eds) Biogenic trace gases: measuring emissions from soil and water. Blackwell Science, Cambridge, MA, p 14-51

Mäkila M (1997) Holocene lateral expansion, peat growth and carbon accumulation on Haukkasuo, a raised bog in southeastern Finland. Boreas 26:1-14

> Mäkila M, Moisanen M (2007) Holocene lateral expansion and carbon accumulation of Luovuoma, a northern fen in Finnish Lapland. Boreas 36:198-210

> McNamara NP, Plant T, Oakley S, Ostle NJ (2008) Gully hotspot contribution to landscape methane and carbon dioxide fluxes in a northern peatland. Sci Total Environ 404:354-360

Milne R, Brown TAW (1997) Carbon in the vegetation and soils of Great Britain. J Environ Manag 49:413-433

Monteith DT, Stoddard JL, Evans CD, de Wit HA and others (2007) Dissolved organic carbon trends resulting from changes in atmospheric deposition chemistry. Nature 450: $537-540$

Neal C (1988) Determination of dissolved $\mathrm{CO}_{2}$ in upland stream water. J Hydrol 99:127-142

> Nilsson M, Sagerfors J, Buffam I, Laudon H and others (2008) Contemporary carbon accumulation in a boreal oligotrophic minerogenic mire: a significant sink after accounting for all C-fluxes. Global Change Biol 14:2317-2332 doi:10.1111/j.1365-2486.2008.01654.x

O'Brien HE, Labadz JC, Butcher DP, Billett MF, Midgley NG (2008) Impact of catchment management upon dissolved organic carbon and stream flows in the Peak District, Derbyshire, UK. In: Sustainable Hydrology for the 21st Century, Proc 10th BHS Nat Hydrol Symp, Exeter, 15-17 Sep 2008. British Hydrological Society, London, p 178-185

Oldfield F, Richardson N, Appleby PG (1995) Radiometric dating $(210 \mathrm{~Pb}, 137 \mathrm{Cs}, 241 \mathrm{Am})$ of recent ombrotrophic peat accumulation and evidence for changes in massbalance. Holocene 5:141-148

Palmer SM, Hope D, Billett MF, Dawson JJC, Bryant CL (2001) Sources of organic and inorganic carbon in a headwater stream: evidence from carbon isotope studies. Biogeochemistry 52:321-338

Pawson RR (2008) Assessing the role of particulates in the fluvial organic carbon flux from eroding peatland systems. $\mathrm{PhD}$ thesis, University of Manchester, Manchester

> Pawson RR, Lord DR, Evans MG, Allott TEH (2008) Fluvial organic carbon flux from an eroding peatland catchment, southern Pennines, UK. Hydrol Earth Syst Sci 12:625-634

> Rose NL, Appleby PG (2005) Regional applications of lake sediment dating by spheroidal carbonaceous particle analysis. I: United Kingdom. J Paleolimnol 34:349-361

Rose NL, Harlock S, Appleby PG, Battarbee RW (1995) Dating of recent lake sediments in the United Kingdom and Ireland using spheroidal carbonaceous particle (SCP) concentration profiles. Holocene 5:328-335

Rothwell JJ (2006) Fluvial export of heavy metals from contaminated and eroding peatlands, southern Pennines, UK. $\mathrm{PhD}$ thesis, University of Manchester, Manchester

Rothwell JJ, Evans MG, Liddaman LC, Allott TEH (2007) The role of wildfire and gully erosion in particulate lead export from contaminated peatland catchments in the southern Pennines. Geomorphology 88:276-284

Roulet N, Lafleur PM, Richard PJH, Moore TR, Humphreys ER, Bubier J (2007) Contemporary carbon balance and late Holocene carbon accumulation in a northern peatland. Global Change Biol 13:397-411 doi:10.1111/j.13652486.2006.01292.x

Simmons IG (2003) The moorlands of England and Wales: an environmental history $8000 \mathrm{BC}$ to AD 2000. Edinburgh University Press, Edinburgh

> Skiba U, Cresser MS, Derwent RG, Futty DW (1989) Peatland acifidification in Scotland. Nature 337:68-69

Smith P, Smith J, Flynn H, Killham K and others (2007) ECOSSE: estimating carbon in organic soils - sequestration and emissions. Scottish Executive Environment and Rural Affairs Department, Edinburgh, www.scotland.gov. uk/Publications/2007/03/16170508/0 
Sykes JM, Lane AMJ (1996) The United Kingdom Environmental Change Network: protocols for standard measurement at terrestrial sites. Her Majesty's Stationery Office, London

Walling DE, Webb BW (1985) Estimating the discharge of contaminants to coastal waters by rivers: some cautionary comments. Mar Pollut Bull 16:488-492

Ward SE, Bardgett RD, McNamara NP, Adamson JK, Ostle NJ (2007) Long-term consequences of grazing and burning on northern peatland carbon dynamics. Ecosystems 10: 1069-1083

Wieder RK, Vitt DH (2006) Boreal peatland ecosystems.

Submitted: November 2, 2009; Accepted: May July 5, 2010
Springer, Berlin

Worrall F, Reed M, Warburton J, Burt TP (2003) Carbon budget for a British upland peat catchment. Sci Total Environ 312:133-146

Worrall F, Burt TP, Rowson JG, Warburton J, Adamson JK (2009) The multi-annual carbon budget of a peat-covered catchment. Sci Total Environ 407:4084-4094

Yang H, Rose NL, Boyle JF, Battarbee RW (2001) Storage and distribution of trace metals and spheroidal carbonaceous particles (SCPs) from atmospheric deposition in the catchment peats of Lochnagar, Scotland. Environ Pollut 115: 231-238

Proofs received from author(s): December 17, 2010 